Portland State University

PDXScholar

$11-27-1974$

\title{
The Development of an Arsenic(V) Selective Electrode
}

Sandra Gee Kang

Portland State University

Follow this and additional works at: https://pdxscholar.library.pdx.edu/open_access_etds

Part of the Analytical Chemistry Commons Let us know how access to this document benefits you.

\section{Recommended Citation}

Kang, Sandra Gee, "The Development of an Arsenic(V) Selective Electrode" (1974). Dissertations and Theses. Paper 2119.

https://doi.org/10.15760/etd.2117

This Thesis is brought to you for free and open access. It has been accepted for inclusion in Dissertations and Theses by an authorized administrator of PDXScholar. Please contact us if we can make this document more accessible: pdxscholar@pdx.edu. 
AN ABSTRACT OF THE THESIS OF Sandra Gee Kang for the Master of Science in Chemistry presented 27 November 1974.

Title: The Development of an Arsenic(V) Selective Electrode

APPROVED BY MEMBERS OF THE THESIS COMMITTEE:

David K. Roe, Chairman

Dennis W. Barnum

Edward M. Perdue

The object of this research was to develop an arsenic(V) selective electrode. The electrode is based on a solid state membrane prepared by pressing a precipitate of silver arsenate-silver sulfide into a pellet. Aftex the electrode was made, experiments were designed to check for three general characteristics of the electrodes: dependence of potential on $\mathrm{pH}$ for constant arsenic(V) concentration; dependence of potential on arsenic(V) concentrations at constant $\mathrm{pH}$ and extent of interference due to phosphate and arsenic(III) ions. From these measurements, it was found that $\mathrm{Ag}_{2} \mathrm{HAsO}_{4}$ was formed originally in the membranes containing a small fraction of arsenic(V) and that this compound was converted to $\mathrm{Ag}_{3} \mathrm{AsO}_{4}$ on the electrode surface in alkaline solutions. 
TO THE OFFICE OF GRADUATE STUDIES AND RESEARCH:

The members of the Committee approve the thesis of Sandra Gee Kang presented 27 November 1974.

David K. Roe, Chairman

Dennis W. Barnum

Edward M. Perdue

APPROVED:

Gary L./Gard, Chairman, Department of Chemistry

David T. Clark, Dean of Graduate Studies 
THE DEVELOPMENT OF AN ARSENIC(V) SELECTIVE ELECTRODE

by

SANDRA GEE KANG

A thesis submitted in partial fulfillment of the requirements for the degree of

\section{MASTER OF SCIENCE}

in

CHEMISTRY

Portland State University

1974 
To My Parents

For Their Understanding and Confidence 


\section{ACKNOWLEDGMENT}

I wish to express my deep appreciation to Dr. David K. Roe for his painstaking guidance, recommendations, and criticisms.

Since I came to the United States, I have had the privilege of serving as a teaching assistant in the Department of Chemistry. I am especially grateful to the University for giving me the opportunity to work closely with the faculty.

I also wish to thank Dr. Gary L. Gard, Chairman of the Department of Chemistry, Dr. Dennis W. Barnum and Dr. Edward M. Perdue for the help and encouragement they extended to me. Finally, thanks to Terence Gleason for his help in the thesis draft. 
ACKNOWLEDGMENTS $\ldots \ldots \ldots \ldots \ldots \ldots \ldots \ldots \ldots \ldots \ldots \ldots \ldots \ldots \ldots \ldots \ldots \ldots \ldots$

LIST OF TABLES $\ldots \ldots \ldots \ldots \ldots \ldots \ldots \ldots \ldots \ldots \ldots \ldots \ldots \ldots \ldots \ldots \ldots$

LIST OF FIGURES $\ldots \ldots \ldots \ldots \ldots \ldots \ldots \ldots \ldots \ldots \ldots \ldots \ldots \ldots \ldots \ldots \ldots \ldots$

INTRODUCTION................................. 1

MATERIALS, APPARATUS AND PREPARATION OF MEMBRANE ELECTRODES..... 6

EXPERIMENTAL PROCEDURE.......................... 10

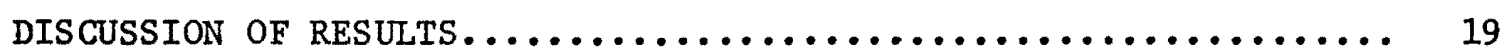

Measurements of Solubility Products................. 19

Optimum $\mathrm{pH}$ for $\operatorname{Arsenic}(\mathrm{V})$ Response.................. 23

Composition of the Membrane.................... 26

Effect of Anodizing Currents and Anodizing Time......... 27

Concentration Range of Arsenic(V) for Useful Response..... 28

Interferences due to Various Ions................. 28

SUMMARY...................................... 34

BIBLIOGRAPHY................................. 36

ARPENDIX......................................... 37 


\section{LIST OF TABLES}

TABLE

PAGE

I Identifcation of Three Electrodes.................. 7

II Solubility Products of Silver Arsenate and Silver

Arsenite from Potentiometric Titrations............... 21

III Dissociation Constants of Inorganic Acids in Aqueous

Solution.................................... 22

IV Selectivity Constants for Various Ions at $\mathrm{pH}=9.0 \ldots \ldots \ldots 31$

V Data and Selectivity, Constants on Phosphate and

Arsenic(III) Interferences.................... 32 


\section{LIST OF FIGURES}

FIGURE

PAGE

1 Model of the Arsenic(V) Selective Electrode............. 8

2 Electrode Response as a Function of $\mathrm{pH}$ for Various

Concentrations of Arsenic(V) Solution................ 11

3 Response of $\mathrm{B}_{1}, \mathrm{~B}_{2}$ Arsenic(V) Sensitive Electrodes vs.

Arsenic(V) Concentration........................ 12

4 The Interference of Various Concentrations of Phosphate

Ion Relative to Arsenic(V) Concentrations of $10^{-6}, 10^{-4}$,

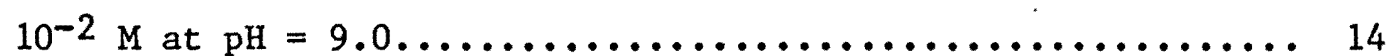

5 The Interference of Various Concentrations of Arsenic(III)

Ion to Arsenic(V) Concentrations of $10^{-5}, 10^{-4}, 10^{-3}$,

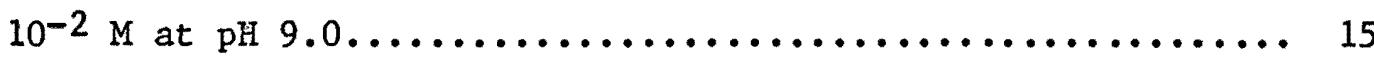

6 Potentiometric Titration of $50.0 \mathrm{ml} 0.0100 \mathrm{M} \mathrm{AgN0} 3$ with

$0.0102 \mathrm{M} \mathrm{Na}_{2} \mathrm{HAsO}_{4}$ at $\mathrm{pH}=8.0$ by Using Silver Ion

Selective Electrode........................... 17

7 Potentiometric Titration of $50.0 \mathrm{ml}$ of $0.0100 \mathrm{M} \mathrm{AgNO} 3$ with

$0.0199 \mathrm{M} \mathrm{As}_{2} \mathrm{O}_{3}$ at $\mathrm{pH} 8.0$ by Using Silver Ion Selective

Electrode................................... 18

8 Response of $\mathrm{B}_{2}, \mathrm{~B}_{3}$ electrode vs. Arsenic(V)

Concentration. 


\section{INTRODUCTION}

Originally, I became interested in analyzing natural waters for arsenic because of a disease prevalent in a village in Taiwan. This disease is reportedly due to accumulation of arsenic in the drinking water. This incidence of arsenic in water is not one of human pollution but rather is due to the course which is followed by the water. It is known that the water flows through some underground tunnels which contain minerals that are high in arsenic before it reaches the community reservoirs. Arsenic is a cumulative poison which builds up slowly in the body. According to some medical sources, long term arsenosis may not be detectable for 2 to 6 years or longer(1). A side effect of arsenic poisoning is the possibility of skin rashes and other types of contact dermatitis in sensitive people. Pentavalent arsenic as arsenate is nontoxic in normal concentrations, is excreted rapidly largely through the kidneys, probably does not accumulate in human tissues, is a normal constituent of food, and may perform some unknown physiological function(2).

Arsenic is introduced into the environment through volcanic eruptions, and is thus found in sedimentary rocks. Due to human activity, increasing amounts of arsenic are being introduced into food and water sources through usage in pigments, herbicides, insecticides, and phosphate laundry detergents.

The U. S. Public Health Service gives tolerances of 10 parts per billion ( $\mathrm{ppb}$ ) (recommended) and $50 \mathrm{ppb}$ (mandatory) of arsenic in drinking water(1). Arsenic values of 2 to $8 \mathrm{ppb}$ have been measured in the Kansas River(1). This clearly is quite close to the critical 
concentration recommended by the Health Department. It is therefore surmised that a rapid, inexpensive, accurate method for measuring arsenic concentration is needed.

It is stated by Myers and Osteryoung that "..the most common methods of arsenic analysis involve the generation of arsine gas followed by the determination of $\mathrm{AsH}_{3}$ according to the Gutzeit method(3), by silver diethyldithiocarbamate(4), by atomic absorption(5-9), or by emission spectroscopy(10). However, it has been reported(11) that. the recovery of small quantities of $\mathrm{AsH}_{3}$ is difficult. Also, it is desirable for an analytical procedure to distinguish between the possible oxidation states of arsenic, and these methods are inherently incapable of such a distinction. While isotope dilution(12) and colorimetric(13, 14) methods can describe the distribution of arsenic between the arsenate and arsenite species, these procedures are slow and tend to be rather insensitive. Thus, electrochemical methods are a reasonable alternative to other analytical techniques"(15).

Voltammetric techniques are commonly used in trace metal work. One particular technique is called polarography. This method is signified by use of a dropping mercury electrode and theoretically deals with the measurement of small electrical currents as a function of applied potential. The determination of the presence of arsenic in its oxidation states and at low concentration has been extensively investigated $(16,17)$. The results of these investigations have been compiled by Arnold and Johnson(18).

In general, it is found that the most complicated and irreversible polarograms occur in noncomplexing acid media, e.g., $\mathrm{HCl}, \mathrm{H}_{2} \mathrm{SO}_{4}, \mathrm{HNO}_{3}$, 
where as in the presence of such complexing agents as tartaric acid, citric acid or pyrogallol, simpler waves are produced. Some polarography was employed in this work to determine arsenic(V) and arsenic(III) in a $2 \mathrm{M} \mathrm{HClO}_{4}-0.5 \mathrm{M}$ pyrogallol medium. Three well defined waves were produced due to reduction of an arsenic(V)-pyrogallol complex to arsenic(III), arsenic(0) and $\mathrm{AsH}_{3}$. These determinations were also conducted using different supporting electrolytes such as $1 \mathrm{M} \mathrm{HC1,} 12 \mathrm{M}$ $\mathrm{HCl}$, or $4 \mathrm{M} \mathrm{HClO}_{4}$ to determine both arsenic(V) and arsenic(III). With these electrolytes, $\mathrm{SnCl}_{4}$ was added in order to generate at the electrode surface a reducing agent, $\mathrm{Sn}^{+2}$, which might reduce arsenic $(\mathrm{V})$ to (III). This would be a catalytic current and could be used to measure the arsenic(V) concentration. The rate of the catalytic reaction was too slow to be useful. Other catalyts were tried without success.

While these experiments were being conducted, a prototype commercial arsenic(V) ion selective electrode was obtained. This electrode, which failed after some experiments was subsequently withdrawn from the market. It was at this time that I decided to construct some electrodes.

During recent years, solid state ion selective membrane electrodes have been constructed which are sensitive to cations and anions as well as complexes. These electrodes have been designed and used for a wide range of analytical applications.

It is observed that electrodes can be made from lanthanum fluoride, silver sulfide, mixed silver sulfide - silve halide, mixed silver sulfide - metal sulfide, etc. Silver sulfide is an ionic conductor of low resistance in which the silver ions are the mobile species. The 
exceedingly low solubility product of $\mathrm{Ag}_{2} \mathrm{~S}$, its excellent resistance to oxidizing and reducing agents, and the ease with which it can be fabricated into dense polycrystalline membranes by conventional pellet pressing techniques, makes it an ideal material for electrode use (19). In this work, precipitates were prepared by adding $\mathrm{AgNO}_{3}$ to aqueous solutions. containing varying amounts of $\mathrm{Na}_{2} \mathrm{~S}$ and $\mathrm{Na}_{2} \mathrm{HAsO}_{4}$. The resulting precipitate was washed, dried, and pressed into a solid pellet which was then made into a membrane electrode.

The response of an ideal solid-state membrane containing $\mathrm{Ag}_{2} \mathrm{~S}$ is determined by the activity of silver ions which in turn is determined by the solubility of silver arsenate in the presence of dissolved arsenate. The potential for a silver sulfide electrode is given by:

$$
\mathrm{E}=\text { constant }+\frac{2.3 \mathrm{RT}}{\mathrm{F}} \log \left[\mathrm{Ag}^{+}\right]
$$

Since silver arsenate is much more soluble than $\mathrm{Ag}_{2} \mathrm{~S}$, the sulfide can be constdered as a chemically inert matrix material through which silver Ions are free to move. At the membrane-solution interface, the silver arsenate equilibrates with the sample solution resulting in a silver ion level given by the solubility of silver arsenate in the presence of dissolved arsenic(V).

$$
\begin{aligned}
{\left[\mathrm{Ag}^{+}\right] } & =\left(\frac{\text { Solubility product of silver arsenate }}{[\mathrm{As}(\mathrm{V})]}\right)^{1 / \mathrm{m}} \\
\mathrm{m} & =\text { mole ratio of silver to arsenic(V) in solid }
\end{aligned}
$$

Substitution into the Nernst equation for a silver ion conducting membrane gives the result that a mixture of this type behaves as though the membrane were a pure arsenic(V) ion conductor.

$$
\mathrm{E}=\text { cons } \tan t-\frac{2.3 \dot{\mathrm{RT}}}{\mathrm{mF}} \log [\mathrm{As}(\mathrm{V})]
$$


After the first set of electrodes was constructed, two types of measurements were made. The experiments inftially were concerned with finding the optimum range of $\mathrm{pH}$ over which the electrodes operate. Secondly, it was necessary to determine over what range of arsenic concentration the electrodes respond. Interferences were expected and I checked initially for problems involving phosphate and arsenic(III) ions because these ions would be expected to be present in water samples. Electrode measurements served my primary purpose; they are fast and a steady reading can be obtained within a few minutes. Also the samples used are in no need of pretreatment except possible pH adjustment and are not subsequently destroyed. One expects that with electrochemical techniques small sample size can be used at low concentration. Construction of the electrodes and related instruments is very simple and quite inexpensive. Future work is needed to develop electrodes of Improved precision. 


\section{MATERIALS, APPARATUS, AND PREPARATION OF MEMBRANE ELECTRODES}

All the chemicals, such as $\mathrm{Na}_{2} \mathrm{~S} \cdot 9 \mathrm{H}_{2} \mathrm{O}, \mathrm{Na}_{2} \mathrm{HAsO}_{4}, \mathrm{AgNO}_{3}$ which were used to form the precipitates were of analytical reagent grade (Mallinckrodt Chemical Works, St. Louis, Missouri) and were used without purification. Distilled water was used throughout these experiments.

The arsenate-sensitive membrane materials were prepared by coprecipitation of silver sulfide and silver arsenate. Different mole ratios of $\mathrm{Na}_{2} \mathrm{~S}$ and $\mathrm{Na}_{2} \mathrm{HAsO}_{4}$ were precipitated by addition of dilute $\mathrm{AgNO}_{3}$ solution, but slightly less than the stoichiometric amount of $\mathrm{AgNO}_{3}$ was added. Many electrodes were constructed in the course of this investigation but the discussion here will be restricted to the three representative electrodes in Table 1. The tabulated moles of $\mathrm{Na}_{2} \mathrm{~S}$ and $\mathrm{Na}_{2} \mathrm{HAsO}_{4}$ which were in a volume of about $200 \mathrm{ml}$ and the moles of $\mathrm{AgNO}_{3}$ which were in a volume of about $800 \mathrm{ml}$. The $\mathrm{pH}$ during the precipitiation was monitored and held at about 6-7 by addition of $1 \mathrm{M} \mathrm{NaOH}$. The precipitations were carried out with rapid stirring.

The precipitate was filtered, very thoroughly washed with hot water then with carbon disulfide, acetone, hot water, and dried in an oven at $110^{\circ} \mathrm{C}$ overnight.

The precipitate was then set in a die with a $13 \mathrm{~mm}$ diameter plunger (Harco Industries, Phoenix, Arizona). Approximately 0.6-0.8 grams of the precipitate was heated on a hot plate to $110^{\circ} \mathrm{C}$, and then was pressed for various lengths of time. The pressure was typically $6000 \mathrm{lbs} / \mathrm{sq}$. in. as indicated by the gauge on the hydraulic jack. The thickness of the disc used in electrode construction was 0.3-0.8 mm. After the disc was removed from the die, a copper wire was attached to one face using a 
TABLE I

IDENTIFICATION OF THREE ELECTRODES

Code

Membrane Material (moles)

$\mathrm{Na}_{2} \mathrm{~S}$

${ }^{B} 1$

0.06

0.06

0.02

$\mathrm{B}_{3}$

$\mathrm{Na}_{2} \mathrm{HAsO}_{4}$
0.01
0.01
0.03

pH While Precipitating

$\mathrm{AgNO}_{3}$

0.12

0.12

0.11
6.2

6.2

6.8 


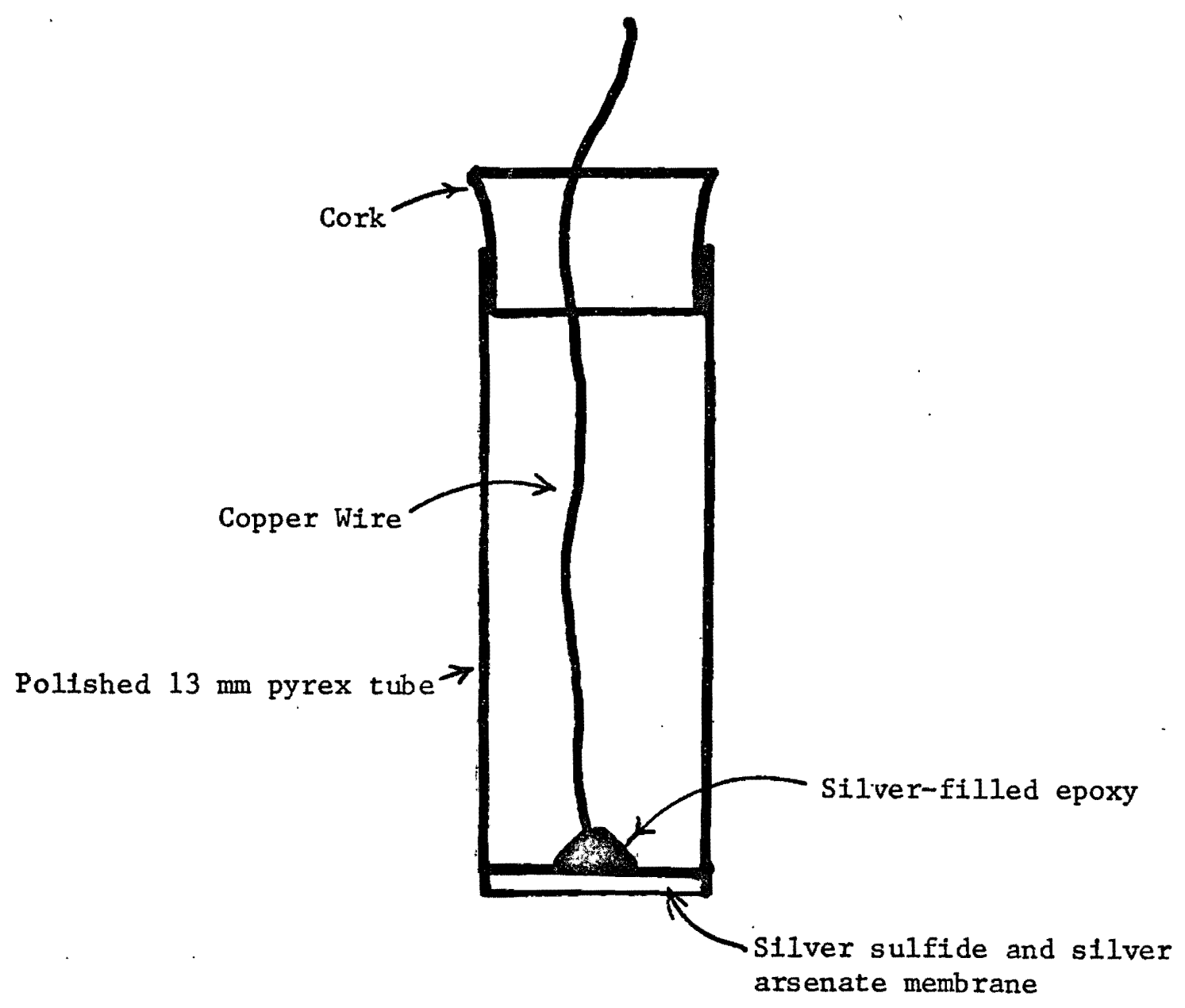

Figure 1. Model of the Arsenic(V) Selective Electrode 
silver-filled epoxy (Cerac, Menomonee Falls, Wisconsin) and cured at $110^{\circ} \mathrm{C}$ for 8 hours. Silicon rubber adhesive was used to secure the disc to the polished end of a $13 \mathrm{~mm}$ pyrex tube. Fig. 1 shows the model of the electrode.

Electrode $B_{1}$ was anodized at applied currents from 0.2 to $1.2 \mathrm{~mA}$ for 2 , to 10 minutes in a solution of $0.2 \mathrm{M} \mathrm{Na}_{2} \mathrm{HAsO}_{4}$ and $0.1 \mathrm{M} \mathrm{KNO}_{3}$. The counter electrode was a carbon rod. Electrode $B_{2}$, however, was not anodized.

The electrodes were stored at room temperature in distilled water and were thoroughly washed and wiped clean before use.

Potentiometric measurements were made in the conventional manner by using the arsenic-sensitive membrane electrode as the indicator electrode and a saturated calomel electrode (Beckman) as the reference electrode which was separated from the tested solution by a $0.1 \mathrm{M}$ potassium nitrate liquid junction. A Data Precision digital voltmeter (Mode1 245) was used. A Corning Model $7 \mathrm{pH}$ meter was used to measure the $\mathrm{pH}$. Adjustment of the meter was made with two buffers, $\mathrm{pH} 6.85$ and $\mathrm{pH} 4.0$. 


\section{EXPERIMENTAL PROCEDURE}

Potentials were measured as a function of arsenic(V) concentration, pH, buffer concentration and arsenic(III) concentration. In all of these measurements, the ionic strength was maintained at $0.1 \mathrm{M}$ by the addition of $\mathrm{KNO}_{3}$. The calomel reference electrode was isolated from the test solution by $0.1 \mathrm{M} \mathrm{KNO}_{3}$ and the liquid junction was made through a porous Vycor plug. A11 measurements were made at room temperature, $23^{\circ}-25^{\circ} \mathrm{C}$.

It was crucial to determine over what $\mathrm{pH}$ range there was no significant change in the potential reading. To achieve this, an experiment was conducted under the conditions of constant arsenic(V) concentration and the $\mathrm{pH}$ was changed over the range of 3 to $12 \mathrm{pH}$ units. The change in $\mathrm{pH}$ was made by additions of either sodium hydroxide to increase the $\mathrm{pH}$ or perchloric acid to decrease the $\mathrm{pH}$; the value was monitored with a pH meter during the measurements. The change of pH was no more than $0.5 \mathrm{pH}$ units for each addition of either acid of base. Results are shown in Figure 2 .

To study the electrode response to arsenic(V) ion, various concentrations of test solutions were prepared. A stock solution of 0.1 $M$ arsenic(V) was prepared from $\mathrm{Na}_{2} \mathrm{HAsO}_{4}$ and then successively diluted down to $10^{-6} \mathrm{M}$. In all solutions the ionic strength was $0.1 \mathrm{M}$ and a dilute buffer established the $\mathrm{pH}$ 9.5. Figure 3 gives the results.

The influence of the phosphate concentration on the electrode response at constant $\mathrm{pH}$ was tested by the following procedure; additions of $0.5 \mathrm{ml}, 1 \mathrm{ml}, 2 \mathrm{ml}, 5 \mathrm{ml}, 10 \mathrm{ml}, 15 \mathrm{ml}, 20 \mathrm{ml}$ of $0.05 \mathrm{~N}$ potassium dihydrogen phosphate was made to a selected concentration of arsenic(V). 


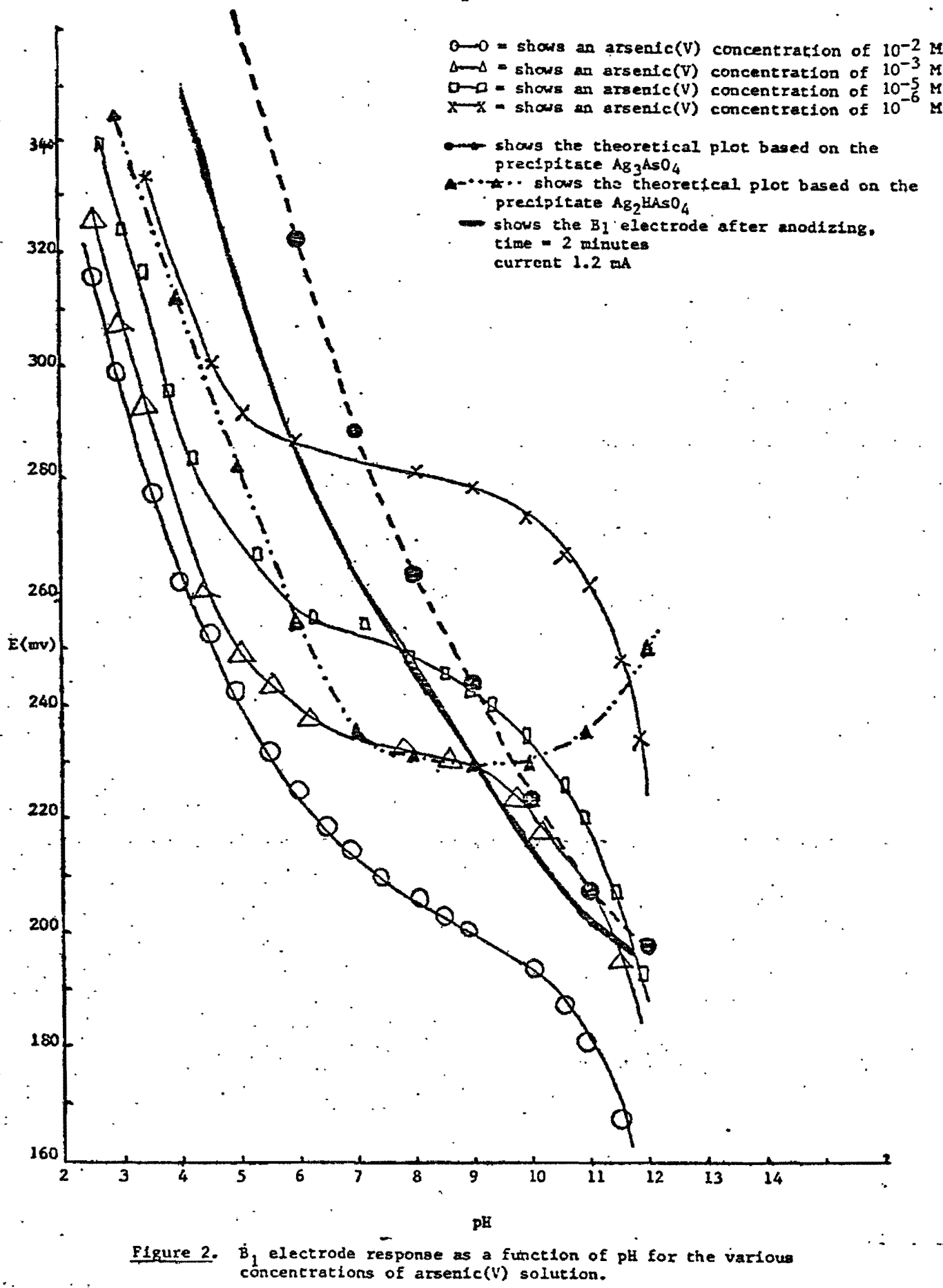




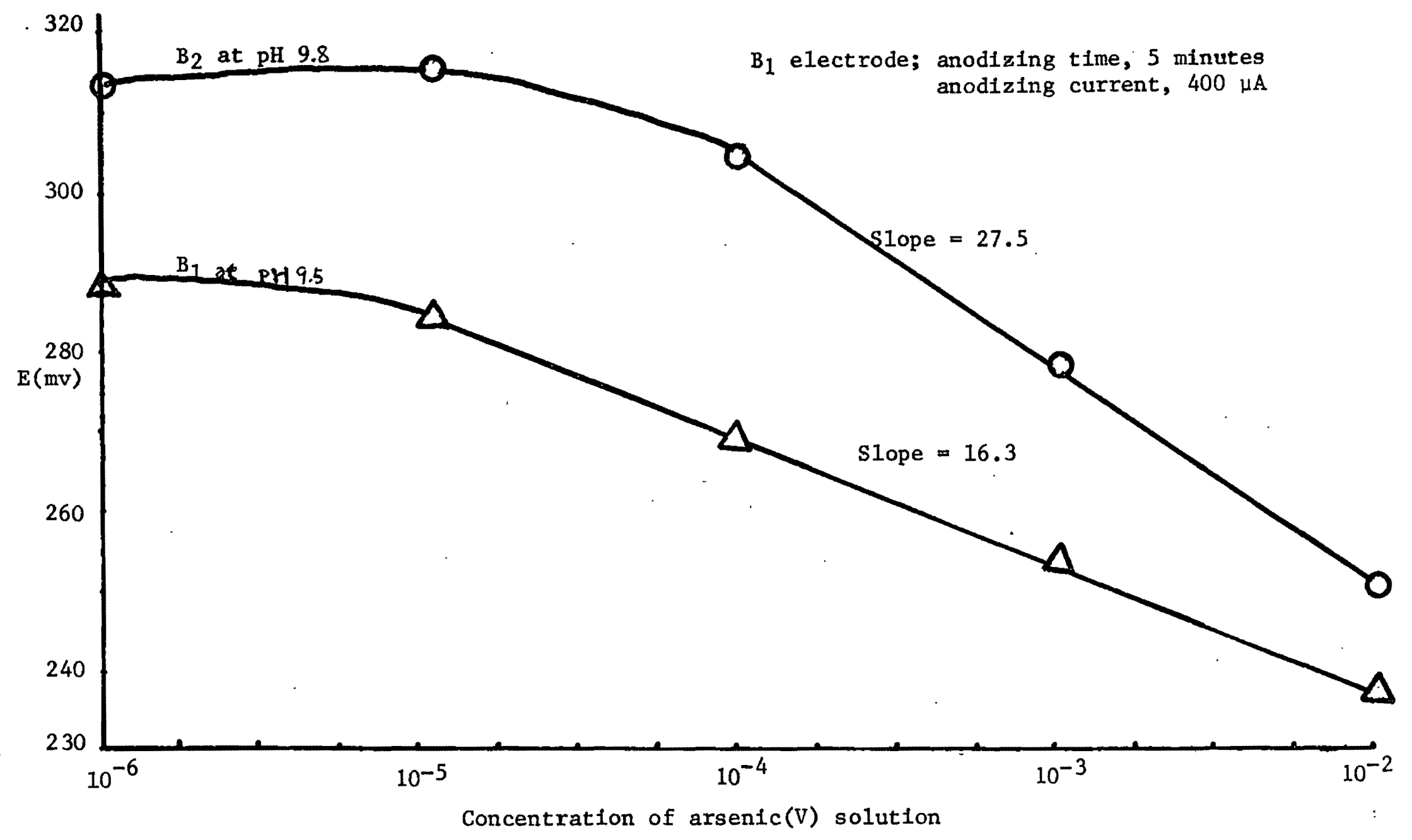

Figure 3. Response of $B_{1}, B_{2}$ arsenic(V) sensitive electrodes vs, arsenic(V) concentration 
The $\mathrm{pH}$ was kept at 9.0 in this case. The results are given in Figure 4. An experiment was designed to determine the effect caused by the presence of arsenic(III) on the potentiometric measurements done in arsenic(V) solutions. The experiments were carried out under constant Ionic strength and constant $\mathrm{pH}$ which was held at 9.00 by using a $10^{-4}$ M phosphate buffer. Each step of the experiment was carried out with a constant concentration of arsenic(V) ions, the decade ranges covered $10^{-5} \mathrm{M}$ to $10^{-2} \mathrm{M}$. In each of the solutions additions of arsenic(III) were made over the range from $10^{-6} \mathrm{M}$ to $10^{-3} \mathrm{M}$. The added volumes were quite small and no significant change in volume resulted. Stock solutions of arsenic(III) were prepared from arsenic trioxide $\left(\mathrm{As}_{2} \mathrm{O}_{3}\right)$ analytical reagent (Mallinckrodt Chem. Works) which first was dissolved in sodium hydroxide, and the $\mathrm{pH}$ adjusted to 9.0 . Figure 5 gives the results.

Generally, all the elctrodes reached a stable potential within 2 minutes. For some cases, solutions were stirred by a Teflon covered magnetic bar in the beaker and a magnetic stirrer. The difference between potential reading with stirring and nonstirring was generally observed to be linearly displaced to a lower potential value.

Between measurements, the electrodes were polished by rubbing on fine emery paper, then rinsed thoroughly with distilled water. Anodization of electrode $B_{1}$ was done before each series of measurements.

The solubilities of silver arsenate and silver arsenite at controlled $\mathrm{pH}$ values were determined from precipitation titrations using a silver ion electrode (Chemtrix, In., Type C800Ag) to follow the concentration changes. For these titrations, $50.0 \mathrm{ml}$ of $0.0100 \mathrm{M} \mathrm{AgNO}_{3}$ was 


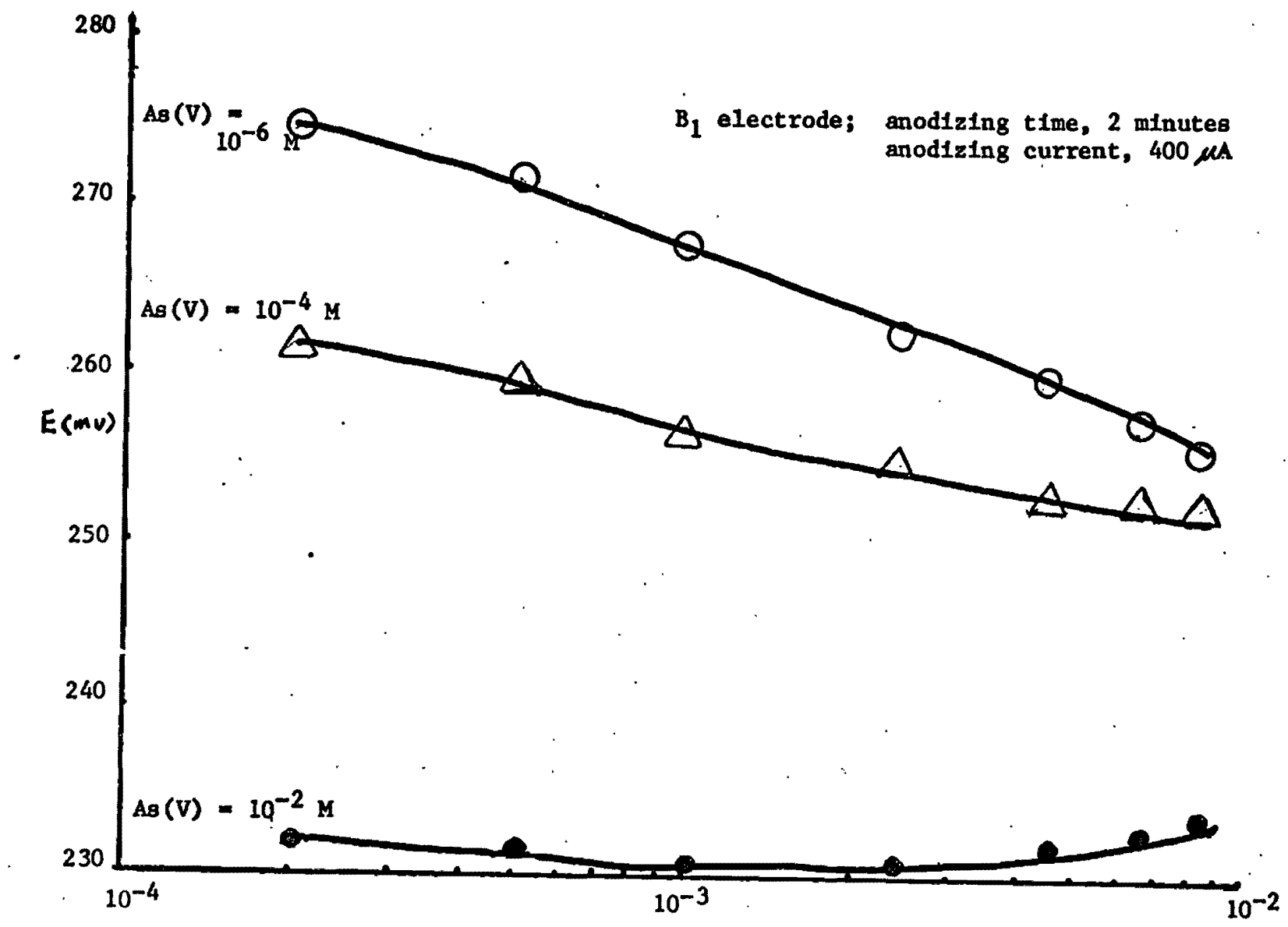

Concentration of Phosphate Ion

Figure 4. The Interference of various concentrations of phosphate ion relative to arsenic(V) concentrations of $10^{-6}, 10^{-4}, 10^{-2} \mathrm{M}$, at $\mathrm{pH}=9.0$. 


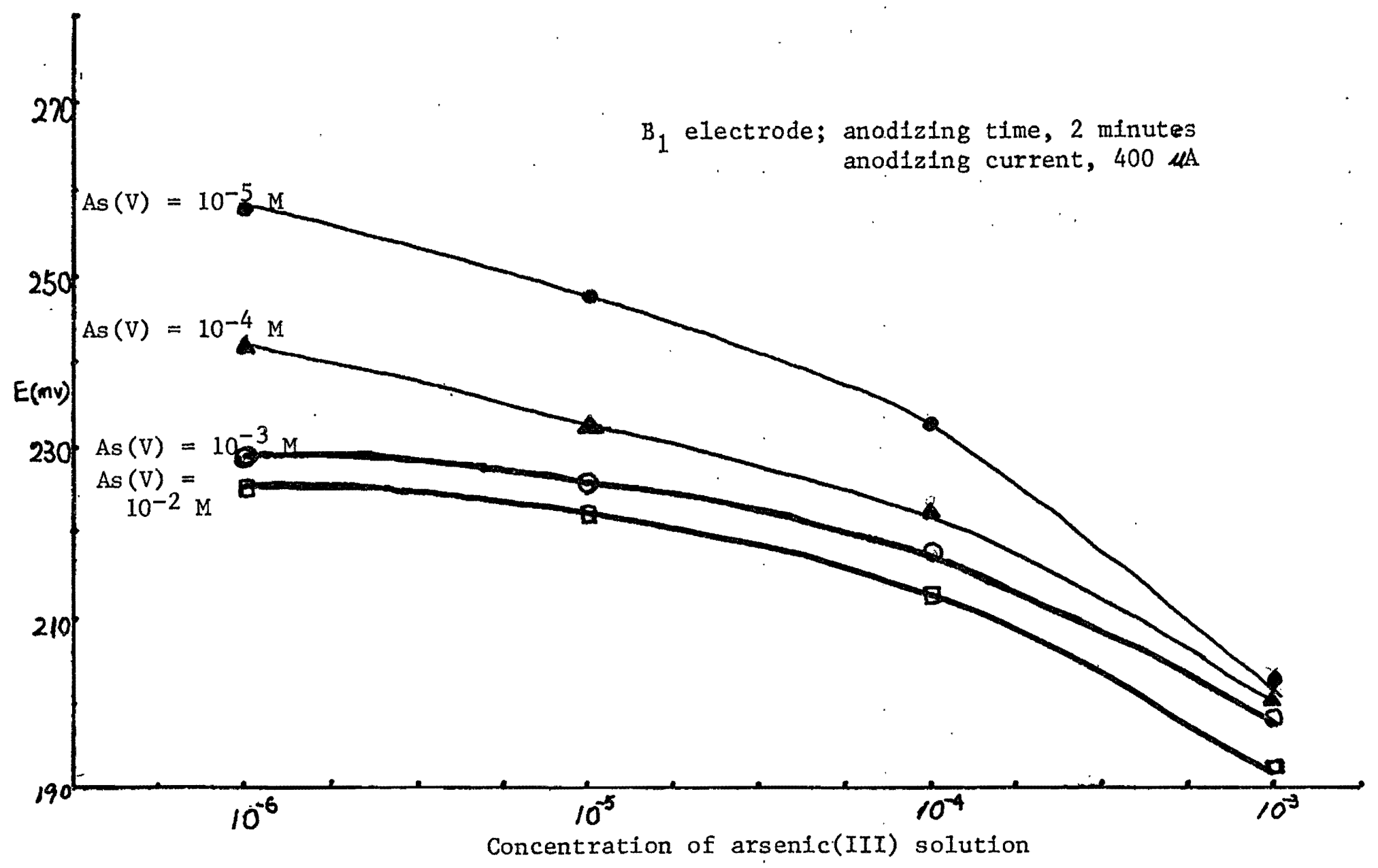

Figure 5. The Interference of various concentrations of arsenic(III) ion to arsenic(V) concentrations of $10^{-5}, 10^{-4}, 10^{-3}, 10^{-2} \mathrm{M}$ at $\mathrm{pH} 9.0$. 
titrated with a $0.0102 \mathrm{M}$ solution prepared from $\mathrm{Na}_{2} \mathrm{HAsO}_{4} \cdot 7 \mathrm{H}_{2} \mathrm{O}$ or with a $0.0199 \mathrm{M}$ solution of $\mathrm{H}_{3} \mathrm{AsO}_{3}$ prepared from $\mathrm{As}_{2} \mathrm{O}_{3}$. During the titrations, the $\mathrm{pH}$ was held at 4.5 or 8.0 , using $0.1 \mathrm{M} \mathrm{NaOH}$ and $0.1 \mathrm{M} \mathrm{HClO}_{4}$ to adjust the $\mathrm{pH}$. At these $\mathrm{pH}$ values, the dominant arsenic(V) species are $\mathrm{H}_{2} \mathrm{AsO}_{4}^{-}$and $\mathrm{HAsO}_{4}^{-2}$, respectively; at $\mathrm{pH}=8.0$, the arsenic (III) species is $\mathrm{H}_{3} \mathrm{AsO}_{3}$. The titration curves are shown in Figures 6 and 7 . 


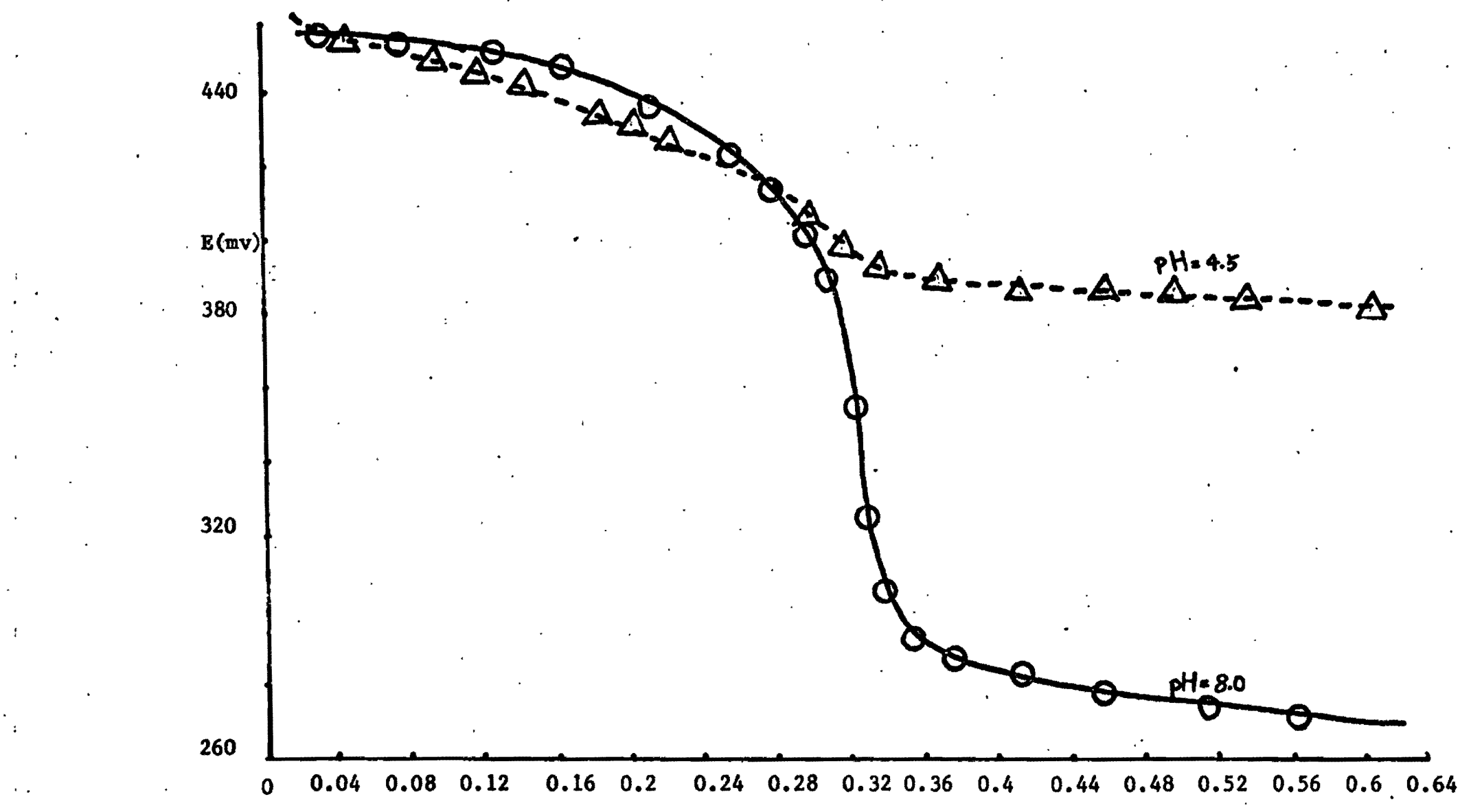

Militate of $\mathrm{As}(\mathrm{V}) / \mathrm{millimole}$ of $\mathrm{Ag}^{+}$

Figure 6. Potentiometric titration of $50.0 \mathrm{ml} 0.0100 \mathrm{M} \mathrm{AgNO}_{3}$ with $0.0102 \mathrm{M} \mathrm{Na}_{2} \mathrm{HAsO}_{4}$ at $\mathrm{pH}=$ 8.0 and $\mathrm{pH}=4.5$, using a silver ion selective electrode. 


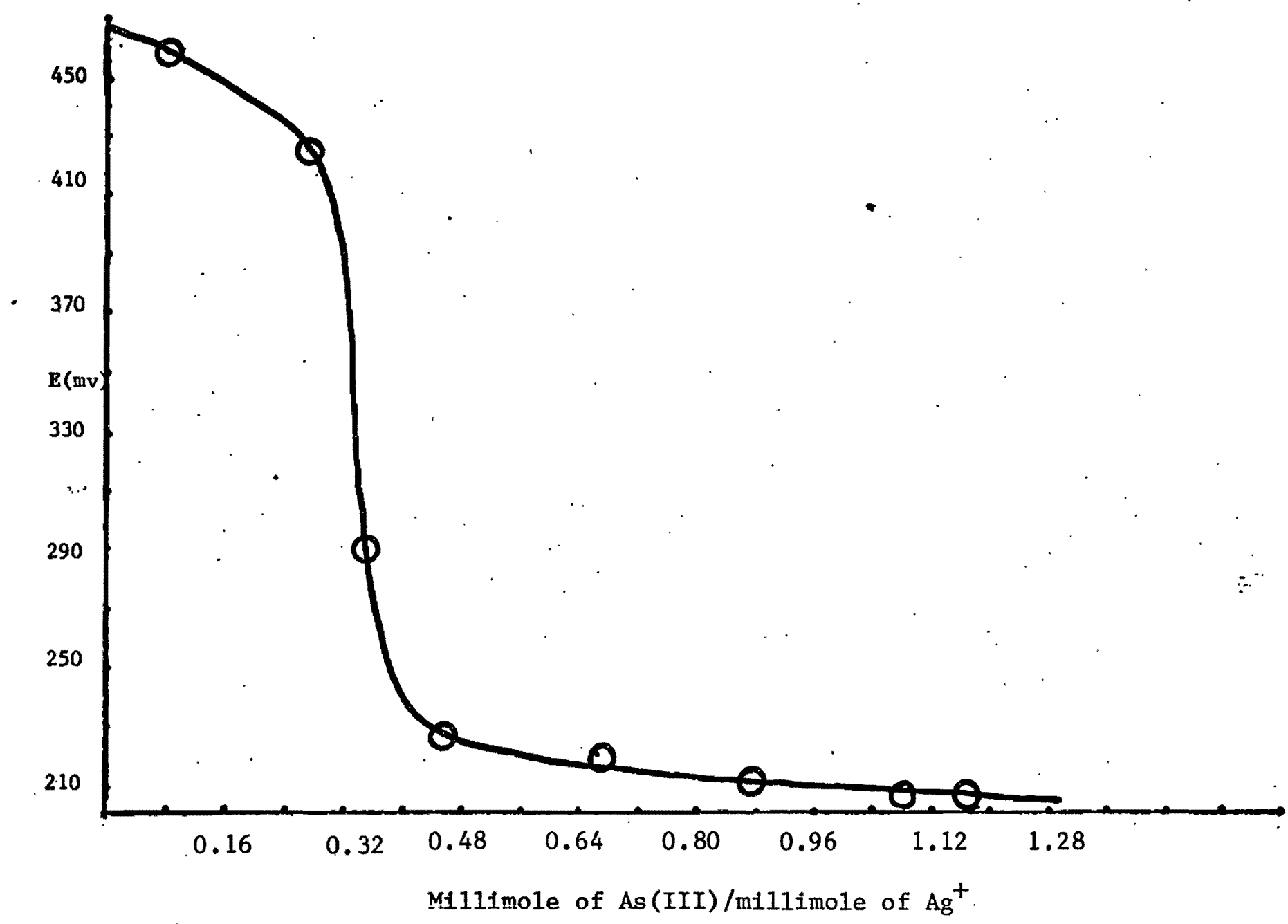

Figure 7. Potentiometric titration of $50.0 \mathrm{ml} 0.0100 \mathrm{M} \mathrm{AgNO}_{3}$ with $0.0199 \mathrm{M} \mathrm{H}_{3} \mathrm{AsO}_{3}$ at $\mathrm{pH} 8.0$ using a silver ion selective electrode 


\section{Measurements of Solubility Products}

Solubility products and the molecular formulas of silver arsenate and silver arsenite were determined from the titration curves shown in Figures 6 and 7. The millimole of $0.0102 \mathrm{M}$ arsenic(V) is onethird the millimole of $0.0100 \mathrm{M}$ silver(I) at $\mathrm{pH}=8$ and nearly the same fraction at $\mathrm{pH}=4.5$. Therefore the mole ratios clearly indicate that the precipitate is $\mathrm{Ag}_{3} \mathrm{AsO}_{4}$, even though the dominant arsenic species is $\mathrm{HAsO}_{4}=$ at $\mathrm{pH}=8$ and $\mathrm{H}_{2} \mathrm{AsO}_{4}^{-}$at $\mathrm{pH}=4.5$. The same considerations reveal that the formula of the silver arsenite precipitate is $\mathrm{Ag}_{3} \mathrm{As}_{3}$ at $\mathrm{pH}=8.0$, since the millimole of $0.0199 \mathrm{M}$ arsenic(III) was onethird of the millimole of $0.0100 \mathrm{M}$ silver(I). The dominant species is $\mathrm{H}_{3} \mathrm{AsO}_{3}$ at $\mathrm{pH}=8.0$.

Calculations of the solubility products were based on the silver(I) concentration at the calculated equivalence point. The silver(I) concentration was determined by comparing the initial potential of the titration with the equivalence point potential using the 'Nernst equation:

$$
E=k+2.3 \frac{\mathrm{RT}}{\mathrm{nF}} \log \left[\mathrm{Ag}^{+}\right]
$$

at the temperature of the titration $23^{\circ} \mathrm{C}$, the coefficient of the $10 \mathrm{~g}$ term is $0.059 \mathrm{v}$. The term $\mathrm{k}$ is a constant for a given silver electrode and reference electrode.

At the beginning of the titration the potential $E_{i}$ is given by $E_{i}=k+0.059 \log \left[\mathrm{Ag}^{+}\right]_{i}$

At the equivalence point of the titration the potential $E_{e q}$ is given by

$$
E_{\text {eq }}=k+0.059 \log \left[\mathrm{Ag}^{+}\right]_{\text {eq }}
$$


Subtracting the equation 2 from equation 3 gives

$$
E_{\text {eq. }}-E_{i}=0.059 \log \frac{\left[\mathrm{Ag}^{+}\right]_{\text {eq }}}{\left[\mathrm{Ag}^{+}\right]_{i}}
$$

Using the data from Figures 6 and $2,\left[\mathrm{Ag}^{+}\right]_{e q}$ was calculated from equation 4 and the results are given in Table II.

The titration reaction of arsenic(V) and silver(I) at $\mathrm{pH}=8.0$ is

$$
3 \mathrm{Ag}^{+}+\mathrm{HAs}_{4}^{-2}=\underset{\leftarrow}{\rightarrow} \mathrm{Ag}_{3} \mathrm{AsO}_{4}+\mathrm{H}^{+}
$$

and at the equivalence point, the concentration of arsenic(V) is $1 / 3$ $\left[\mathrm{Ag}^{+}\right]_{e q}$, or $\left[\mathrm{HAsO}_{4}^{-2}\right]=1.47 \times 10^{-5} \mathrm{M}$, since $\mathrm{HAsO}_{4}^{-2}$ is the dominant species at $\mathrm{pH}=8.0$. The equilibrium constant for this reaction, written as an apparent solubility product, $\mathrm{K}_{\mathrm{s}_{\mathrm{p}}}$, is

$$
\mathrm{K}_{\mathrm{sp}}^{\prime}=\frac{\left[\mathrm{Ag}^{+}\right]^{3}\left[\mathrm{HAsO}_{4}=\right]}{\left[\mathrm{H}^{+}\right]}
$$

but the dissociation constant for $\mathrm{HAs}_{4}=$ is

$$
\mathrm{K}_{3}=\frac{\left[\mathrm{AsO}_{4}^{-3}\right]\left[\mathrm{H}^{+}\right]}{\left[\mathrm{HAsO}_{4}=\right]}=3.95 \times 10^{-12}
$$

The three dissociation constants for the arsenic acid are given in Table III. So the solubility product for $\mathrm{Ag}_{3} \mathrm{AsO}_{4}, \mathrm{~K}_{5 p}$ is given by

$$
\mathrm{Ksp}=\mathrm{K}_{\mathrm{sp}}^{\prime} \mathrm{K}_{3}
$$

The calculated value is given in Table II and may be compared with the Iiterature value of $1.08 \times 10^{-22}$ at $20^{\circ} \mathrm{C}(20)$.

At $\mathrm{pH}=4.5$, the titration reaction is

$$
3 \mathrm{Ag}^{+}+\mathrm{H}_{2} \mathrm{AsO}_{4}^{-} \rightleftarrows \mathrm{Ag}_{3} \mathrm{AsO}_{4}+2 \mathrm{H}^{+}
$$

In a similar manner, the apparent solubility product for this reaction is given by

$$
\mathrm{Ksp}^{\prime \prime}=\frac{\left[\mathrm{Ag}^{+}\right]^{3}\left[\mathrm{H}_{2} \mathrm{AsO}_{4}^{-}\right]}{\left[\mathrm{H}^{+}\right]^{2}}
$$


TABLE II

SOLUBILITY PRODUCTS OF SILVER ARSENATE AND SILVER ARSENITE FROM POTENTIOMETRIC TITRATIONS

\begin{tabular}{|c|c|c|c|c|c|c|c|c|}
\hline Titrant & $\mathrm{pH}$ & $\mathrm{E}_{\mathbf{j}} \mathrm{mv}$ & $\mathrm{E}_{\text {eq }} \mathrm{mv}$ & {$\left[\mathrm{Ag}^{+}\right]_{i}$} & {$\left[\mathrm{Ag}^{+} \mathrm{leq}\right.$} & [As (V) leq & $\mathrm{Kgp}^{*}$ & Solid Phase \\
\hline $\mathrm{HAsO}_{4}=$ & 8.0 & 463 & 324 & $0.0100 \mathrm{M}$ & $4.41 \times 10^{-5}$ & $1.47 \times 10^{-5} \mathrm{M}$ & $5.0 \times 10^{-22}$ & $\mathrm{Ag}_{3} \mathrm{AsO}_{4}$ \\
\hline $\mathrm{H}_{2} \mathrm{AsO}_{4}^{-}$ & 4.5 & 460 & 396 & $0.0100 \mathrm{M}$ & $8.23 \times 10^{-4}$ & $2.74 \times 10^{-4} \mathrm{M}$ & $1.0 \times 10^{-22}$ & $\mathrm{Ag}_{3} \mathrm{AsO}_{4}$ \\
\hline $\mathrm{H}_{3} \mathrm{AsO}_{3}$ & 8.0 & 466 & 310 & $0.0100 \mathrm{M}$ & $2.27 \times 10^{-5}$ & $7.6 \times 10^{-6} \mathrm{M}$ & $5.3 \times 10^{-13}$ & $\mathrm{Ag}_{3} \mathrm{AsO}_{3}$ \\
\hline
\end{tabular}

* Solubility product at an Ionic strength about $0.1 \mathrm{M}$ for the reactions:

$$
\begin{aligned}
& \mathrm{Ag}_{3} \mathrm{AsO}_{4} \neq 3 \mathrm{Ag}^{+}+\mathrm{AsO}_{4}^{-3} \text { and } \\
& \mathrm{Ag}_{3} \mathrm{AsO}_{3}+2 \mathrm{H}^{+} ₹ 3 \mathrm{Ag}^{+}+\mathrm{H}_{2} \mathrm{AsO}_{3}^{-}
\end{aligned}
$$


TABLE III

DISSOCIATION CONSTANTS OF INORGANIC ACIDS

IN AQUEOUS SOLUTIONS

\begin{tabular}{|c|c|c|c|c|c|}
\hline Acid & $\mathrm{T}^{\circ} \mathrm{C}$ & Step & $\mathrm{K}$ & $\perp^{\mathrm{pK}}$ & Reference \\
\hline Arsenic acid & $25^{\circ} \mathrm{C}$ & 1 & $5.62 \times 10^{-3}$ & $2: 25$ & (21) \\
\hline Arsenic acid & $25^{\circ} \mathrm{C}$ & 2 & $1.70 \times 10^{-7}$ & 6.77 & (21) \\
\hline Arsenic acid & $25^{\circ} \mathrm{C}$ & 3 & $3.95 \times 10^{-12}$ & 11.60 & (21) \\
\hline Arsenious acid & $25^{\circ} \mathrm{C}$ & 1 & $6 \times 10^{-10}$ & 9.23 & (21) \\
\hline Arsenious acid & $25^{\circ} \mathrm{C}$ & 2 & $3 \times 10^{-14}$ & 13.5 & \\
\hline Phosphoric actd & $25^{\circ} \mathrm{C}$ & 1 & $7.52 \times 10^{-3}$ & 2.12 & $(22)$ \\
\hline Phosphoric acid & $25^{\circ} \mathrm{C}$ & 2 & $6.23 \times 10^{-8}$ & 7.20 & $(22)$ \\
\hline Phosphoric acid & $25^{\circ} \mathrm{C}$ & 3 & $2.2 \times 10^{-13}$ & 12.4 & $(22)$ \\
\hline
\end{tabular}


Since the dominant arsenic species is $\mathrm{H}_{2} \mathrm{As}_{4}{ }^{-}$, its concentration at the equivalence point is $1 / 3\left[\mathrm{Ag}^{+}\right]_{\text {eq }}$ or $2.74 \times 10^{-4} \mathrm{M}$. Including the second dissociation step of arsenic acid, $\mathrm{K}_{2}=1.70 \times 10^{-7}$ (Table III) gives

$$
\mathrm{K}_{\mathrm{sp}}=\mathrm{K}_{\mathrm{sp}} " \mathrm{~K}_{2} \mathrm{~K}_{3}
$$

This value of Ksp $1.0 \times 10^{-22}$, listed in Table II agrees better with the literature value, but the titration curve is not very good.

Silver arsenite at $\mathrm{pH}=8.0$ dissolves according to the reverse of the titration reaction

$$
3 \mathrm{Ag}^{+}+\mathrm{H}_{3} \mathrm{AsO}_{3} \neq \mathrm{Ag}_{3} \mathrm{AsO}_{3}+3 \mathrm{H}^{+}
$$

However, arsenious acid is very weak and the third dissociation constant has not been measured. For the first dissociation, $k_{1}=6.0 \times 10^{-10}$ and for the second, $\mathrm{K}_{2}=3 \times 10^{-14}$. Since it is not possible to obtain a solubility product which is independent of $\mathrm{pH}$, the constant has been calculated for

$$
\mathrm{Ag}_{3} \mathrm{AsO}_{3}+2 \mathrm{H}^{+}+3 \mathrm{Ag}^{+}+\mathrm{H}_{2} \mathrm{AsO}_{3}^{-}
$$

Using the same equation as before, the calculation of the solubility product follows from the data of the titration curve and $K_{S p}=K_{S i p} K_{1}$. The result is given in Table II. Although this solubility product is considerably larger than the constant for $\mathrm{Ag}_{3} \mathrm{AsO}_{4}$, the concentration of silver(I) is smaller at a given $\mathrm{pH}$ due to the protons in the reaction involving arsenite.

\section{Optimum pH for Arsenic(V) Response}

The measurements of potential over the $\mathrm{pH}$ range of 2.5 to 12 reveals not only the optimum $\mathrm{pH}$ range but also several important characterlstics of the electrode. In Figure 2, electrode $B_{1}$ has a plateau in potentlal from $\mathrm{pH}$ values of 6 to 9 ; the plateau is very distinct at low 
arsenic( $V$ ) concentrations but with time at $10^{-2} \mathrm{M}$ arsenic( $V$ ) the curve became rather steep. Since electrode $B_{1}$ was not anodized just before these measurements, the behavior is the same as that of $B_{2}$. The plateau suggests that the electrode responds to the ion $\mathrm{HAsO}_{4}^{--}$since this is the dominant species over this $\mathrm{pH}$ range. Theoretical plots are given in Figure 2 for this case and for the case where the response is due to $\mathrm{AsO}_{4}{ }^{-3}$, the derivation of the equations for these curves is in the Appendix. It is evident that the experimental curves agree well with the slope of the theoretical curve for $\mathrm{HAsO}_{4}^{-2}$ up to $\mathrm{pH} 9$, but then beyond this $\mathrm{pH}$ the agreement is with the theoretical curve for $\mathrm{AsO}_{4}^{-3}$. Since these measurements were made from low to high $\mathrm{pH}$ values it appears that the electrode contained initially $\mathrm{Ag}_{2} \mathrm{HAsO}_{4}$ which was converted to $\mathrm{Ag}_{3} \mathrm{AsO}_{4}$ in alkaline solutions. It would be expected that the conversion would be time and concentration dependent and this is why the curve in Figure 2 for $10^{-2} \mathrm{M}$ arsenic(V) does not have a distinct plateau. Also, If the $\mathrm{pH}$ was decreased during these measurements, the potentials were not reproducible but were lower. Such hysterises clearly is due to a change in the electrode.

When electrode $B_{1}$ was anodized in an arsenic(V) solution, and then used to determine the effect of $\mathrm{pH}$, the curve, as shown in Figure 2, agreed in shape with the theoretical plot for response to the $\mathrm{As}_{4}{ }^{-3}$ ion. It is expected that $\mathrm{Ag}_{3} \mathrm{AsO}_{4}$ forms on the electrode surface during anodization since this is the only compound that was found in the potentlometric titration curves regardless of $\mathrm{pH}$ (see Figure 6). It remains then, to explain why electrodes of the composition used for $B_{1}$ and $\mathrm{B}_{2}$ responded initially to the ion $\mathrm{HAsO}_{4}^{-2}$. The most direct reason 


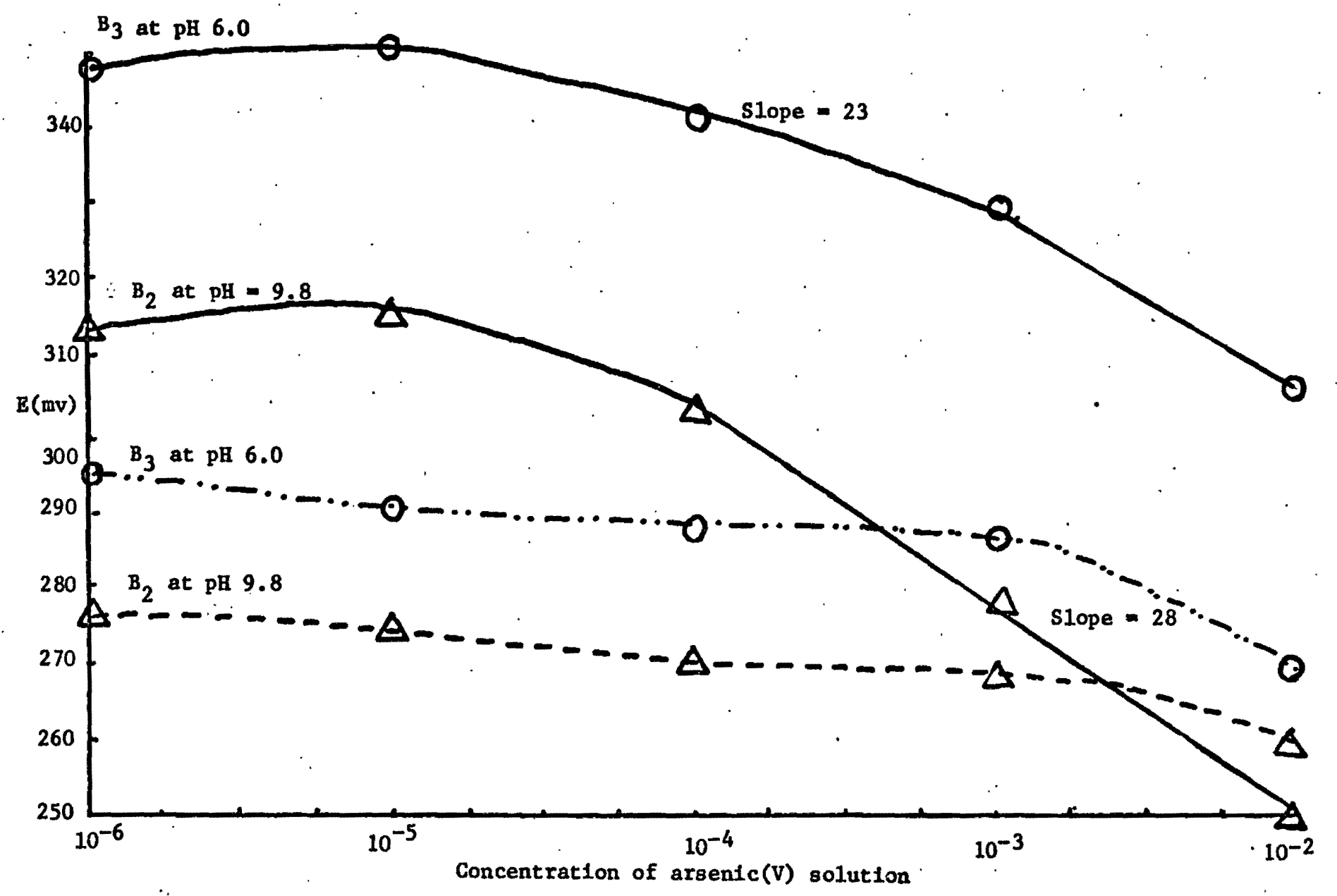

P1gure 8. Response of $B_{2}, B_{3}$ electrodes vs. arsenic concentration.

- - experiments done before exposure to solutions of $\mathrm{pH} 12$.

Two electrodes were used, $B_{2}$ and $B_{3}$ 
is that this ion is preferentally incorporated into the $\mathrm{Ag}_{2} \mathrm{~S}$ lattice during the coprecipitation because the ionic charge is the same as that of sulfide ion. With time and exposure to alkaline solutions, the $\mathrm{Ag}_{2} \mathrm{HAsO}_{4}$ is converted to $\mathrm{Ag}_{3} \mathrm{AsO}_{4}$ because the latter is much more insouble.

Composition of the Membrane

Figure 8 indicates a marked change in the potential response to the arsenic $(V)$ concentration of $B_{2}$ and $B_{3}$ electrodes after exposure to solutions of $\mathrm{pH} 12$ and arsenic(V) concentration of $10^{-2} \mathrm{M}$. It is observed that there were almost no potential response for both electrodes whereas before, the potential changes were normal. This is an extreme case and can be explained by the formation on the electrode surface of a heavy $\mathrm{Ag}_{3} \mathrm{AsO}_{4}$ layer which is a non-ionic conductor. Similar results also were obtained when electrode $B_{1}$ was anodized for a long time. These observations agree with the preceeding conclusions that the electrodes undergo changes with time under certain conditions.

Notice that in Figure 8, the slopes of the measurements before contact with high $\mathrm{pH}$ solutions indicate that $\mathrm{Ag}_{2} \mathrm{HAsO}_{4}$ and $\mathrm{Ag}_{3} \mathrm{AsO}_{4}$ were initially present on the surface of electrodes $B_{2}$ and $B_{3}$, respectively, since the slopes are approximately 30 and $20 \mathrm{mv} \cdot /$ decade. These conclusions are arrived at by use of the Nersnt equation:

$$
\mathrm{E}=\mathrm{k}-0.059 / \mathrm{m} \log [\mathrm{As}(\mathrm{V})]
$$

The slopes stated above are equal to $0.059 / \mathrm{m}$, where $\mathrm{m}$ is the mole ratio of silver to arsenate $(V)$ in the solid. So for electrode $B_{2}$, the value of $m$ must be 2 and for $B_{3}$ the value of $m$ must be 3 . The composition of these two electrodes is given in Table $1 ; B_{2}$ contains no more than 16 mole percent of arsenate and $B_{3}$ contains about 60 mole percent of 
arsenate. In the precipitation process, $\mathrm{HAsO}_{4}^{-2}$ was apparently incorportated into the crystal lattices of $\mathrm{Ag}_{2} \mathrm{~S}$ when the latter was in excess. However, when the arsenate was in excess, it is quite reasonable to assume that $\mathrm{Ag}_{3} \mathrm{AsO}_{4}$ formed as a separate phase mixed with $\mathrm{Ag}_{2} \mathrm{~S}$.

In the formation of the membrane materials, it is perferable to lower the $\mathrm{pH}$ below 10 to avoid $\mathrm{Ag}_{2} \mathrm{O}$ formation. $\mathrm{Ag}_{2} \mathrm{O}$ is an electronic conductor and the electrodes should be only ionic conductors. The presence of $\mathrm{Ag}_{2} \mathrm{O}$ gives poor selectivity and sluggish electrode potential response to arsenic(V) solutions.

Effect of Anodizing Currents and Anodizing Times

Since silver arsenate can be dissolved out of the membrane surface with time, especially at low $\mathrm{pH}$ values, attempts were made to reform silver arsenate on the electrode surface by anodizing in a solution of $0.2 \mathrm{M} \mathrm{Na}_{2} \mathrm{HAs}_{4} 4^{\circ}$ To improve solution conductivity, $\mathrm{KNO}_{3}$ was added.

Different anodizing times and currents were tried in the anodization of the electrodes. There was no large change in potential as long as the time and current were kept within several minutes and between 0.2 to $1.2 \mathrm{~mA}$. Anodizing the electrode served to build a thin silver arsenate layer on $\mathrm{Ag}_{3} \mathrm{AsO}_{4}$ on the surface of the electrode membrane. Silver ions are mobile and move through the silver sulfide. At the membrane surface silver arsenate formed by reaction of silver ions with arsenate from the solution. If the matrix was anodized too long, the $\mathrm{Ag}_{3} \mathrm{AsO}_{4}$ layer became too thick and acted as an insulator resulting in non-nernstian behavior. When a large current was used to anodize the electrode, the $\mathrm{Ag}_{3} \mathrm{AsO}_{4}$ layer adsorbed irregularly, resulting in a poorly 
amorphous appearing layer which also gave non-nerstian behavior.

It was found experimentally that a new electrode surface could be obtained by dipping the electrode in perchloric acid. Good results were obtained when the electrode was allowed to stand in dilute perchloric acid for approximately 15 minutes. While perchloric acid is necessary whenever adsorbed lons are to be removed, distilled water is sufficient for routine washing.

Concentration Range of Arsenic(V) for Useful Response

An experiment was designed to determine over what range of arsenic(V) concentrations the electrodes would be useful. Two calibration curves of arsenic(v) sensitive electrodes are shown in Figure 3. Both of the electrodes have been pressed from the same precipitate. The electrode identified as $B_{1}$ was anodized with a current $400 \mu \mathrm{A}$ for 5 minutes while the electrode $B_{2}$ was not. Nernstian response for both electrodes was obtained over a range extending from $10^{-5} \mathrm{M}$ to $10^{-2} \mathrm{M}$. The average slopes of the curves were calculated to be 27.5 and 16.3 per decade change in arsenic(V) concentration for the electrodes $B_{2}$ and $B_{1}$, respectively. Concentrations below $10^{-5} \mathrm{M}$ arsenic(V) are below the detection limits of the electrodes and the constant potential response is indicated by a plateau seen in both calibration curves.

\section{Interference due to Various Ions}

Nernstian response in an arsenic(V) membrane device requires that the membrane be in equilibrium with only the arsenate ion in the sample solution. This will not be the case if there are interfering species present in the sample solution which can react with the components of 
the membrane. The most common type of reaction involves an ion in the sample solution which also forms an insoluble silver salt. Phosphate Ion, for example, can interfere with arsenic(V) measurements if the reaction

$$
\mathrm{PO}_{4}^{-3}+\mathrm{Ag}_{3} \mathrm{AsO}_{4} \rightarrow \mathrm{Ag}_{3} \mathrm{PO}_{4}+\mathrm{AsO}_{4}{ }^{-3}
$$

takes place.

This reaction will not proceed to the right unless the ratio of the phosphate ion activity to the arsenate ion activity exceeds a value given by the ratio of the solubility products of silver phosphate to silver arsenate, assuming that the activity ratio of the two solids is constant.

Pungor has given a generalized equation(23), which for a bromide electrode"in the presence of several anions (ittcluditig bromide) takes the form:

$$
E=\text { constant }-\left(\frac{R T}{F}\right) \text { ln }\left[A_{B r}+\sum_{i}^{\sum} K_{B r-i}\left(\frac{A_{i}}{A_{B r}}\right)\right]
$$

where $A_{B r}, A_{i}$ are the bromide and anion activity and $\mathrm{K}_{\mathrm{Br}-1}$ is the selectivity constant.

For the arsenic(V) sensitive electrodes in the presence of interfering ions $\mathrm{x}^{-\mathrm{m}}$, we can rewrite this equation as follows:

$$
E=\text { constant }-\left(\frac{R T}{m F}\right) \ln \left(A_{A s}+K_{A s-X} A_{X}\right)
$$

and the selectivity constant is interpreted in terms of the equilibrium constant for the exchange process

$$
\begin{gathered}
\mathrm{Ag}_{3} \mathrm{AsO}_{4}+\frac{3}{\mathrm{~m}^{-m}} \div \frac{3}{\mathrm{~m}} \mathrm{Ag}_{\mathrm{m}} \mathrm{X}+\mathrm{AsO}_{4}{ }^{-3} \\
\mathrm{~K}_{\mathrm{As}-\mathrm{X}}=\frac{\cdot\left(\mathrm{Ag}_{\mathrm{m}} \mathrm{X}\right) 3 / \mathrm{m}\left(\mathrm{AsO}_{4}^{-3}\right)}{\left(\mathrm{Ag}_{3} \mathrm{AsO}_{4}\right)\left(\mathrm{X}^{-\mathrm{m}}\right)^{3 / \mathrm{m}}}
\end{gathered}
$$


Usually, the activity ratio of the solid phase is assumed to be unity. Multiplying the numerator and denominator by $\left(\mathrm{Ag}^{+}\right)^{3}$, the selectivity constant becomes

$$
k_{A s-X}=\frac{\left(\mathrm{Ag}^{+}\right)^{3}\left(\mathrm{AsO}_{4}^{-3}\right)}{\left(\mathrm{Ag}^{+}\right)^{3}\left(\mathrm{X}^{-\mathrm{m}}\right)^{3 / \mathrm{m}}}=\frac{\left(\mathrm{K}_{S p}\right) \mathrm{As}}{\left(\mathrm{K}_{s p}\right)_{x}^{3 / \mathrm{m}}}
$$

where $\left(K_{S p}\right)_{X}=\left(\mathrm{Ag}^{+}\right)^{\mathrm{m}}\left(\mathrm{X}^{-\mathrm{m}}\right)$ and m may be $1,2,3, \ldots \ldots$

From this gemeral equation, approximate values of the selectivity constant can be calculated; values for some common ions are listed in Table IV. If the ion $\mathrm{X}^{-\mathrm{m}}$ is protonated at the $\mathrm{pH}$ of the measurement, the apparent solubility product must be used in the above equation. Also, if the arsenic(V) species is not as written, a similar correction is necessary.

For the samewarsenic(V) concentration; but different" concentrations of the interfering ions $\mathrm{x}^{-\mathrm{m}}$, one equation may be obtained as follows:

$$
E_{1}-E_{2}=\frac{0.059}{3} \log \frac{[A s(V)]+K A s-X\left[X^{-m}\right]_{I}}{[A s(V)]+K A s-X\left[X^{-m}\right]_{2}}
$$

where $E_{1}$ and $\left[X^{-m}\right]_{1}$ are the potential and ion concentration at condition 1 and

$E_{2}$ and $\left[\mathrm{X}^{-\mathrm{m}}\right]_{2}$ are the potential and fon concentration at condition 2 .

Since the ionic strength of the solution was kept eonstant, the fon concentration was used instead of ion activity. Then the selectivity constant can be calculated by means of the following expression:

$$
\frac{[A s(V)]+\mathrm{KAs}-\mathrm{X}\left[\mathrm{X}^{-\mathrm{m}}\right]_{1}}{[\mathrm{As}(\mathrm{V})]+\mathrm{KAs}-\mathrm{X}\left[\mathrm{X}^{-\mathrm{m}}\right]_{2}}=10 \frac{-\left(\mathrm{E}_{1}-\mathrm{E}_{2}\right)}{0.02}
$$

The experimental data and selectivity constants are listed in Table, V. 
TABLE IV

SELECTIVITY CONSTANT FOR VARIOUS IONS AT $\mathrm{pH}=9.0$

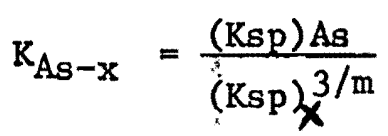

Ion $\mathrm{x}^{-\mathrm{m}}$

Solubility Product of $\mathrm{Ag}_{m} \mathrm{X}$
Selectivity Constant

$\mathrm{K}_{\text {As }-X}$

\begin{tabular}{|c|c|c|}
\hline $\mathrm{PO}_{4}^{-3}$ & $\mathrm{Ag}_{3} \mathrm{PO}_{4}$ & $1.3 \times 10^{-20}$ \\
\hline As (III) & $\mathrm{Ag}_{3} \mathrm{AsO}_{3}$ & $5.3 \times 10^{-13}$ \\
\hline $\mathrm{Br}^{-}$ & $\mathrm{AgBr}$ & $7.7 \times 10^{-13}$ \\
\hline $\mathrm{Cl}^{-}$ & $\mathrm{AgCl}$ & $1.56 \times 10^{-10}$ \\
\hline $\mathrm{I}^{-}$ & AgI & $1.5 \times 10^{-16}$ \\
\hline
\end{tabular}

$4.3 \times 10^{-4}$

$1.8 \times 10^{1}$

$5.5 \times 10^{25}$

$6.7 \times 10^{18}$

$7.5 \times 10^{34}$ 


\section{TABLE $\quad V$}

DATA AND SELECTIVITY CONSTANTS FROM THE EXPERIMENTS OF PHOSPHATE AND ARSENIC(III) INTERFERENCE

\begin{tabular}{|c|c|c|c|c|c|}
\hline $\begin{array}{l}\text { Arsenic(V) } \\
\text { Concentration }\end{array}$ & $\begin{array}{l}\text { Phosphate }\left[\mathrm{PO}_{4}^{-3}\right]_{1} \\
\text { Concentration }\end{array}$ & $\begin{array}{l}\text { Phosphate }\left[\mathrm{PO}_{4}^{-3}\right]_{2} \\
\text { Concentration }\end{array}$ & $\begin{array}{l}\mathrm{E}_{1} \\
\mathrm{mv}\end{array}$ & $\begin{array}{l}\mathrm{E}_{2} \\
\mathrm{mv}\end{array}$ & Ks c \\
\hline $10^{-6}$ & $2.0 \times 10^{-4}$ & $8.3 \times 10^{-3}$ & 274.5 & 255.5 & $1.22 \times 10^{-3}$ \\
\hline $10^{-4}$ & $2.0 \times 10^{-4}$ & $8.3 \times 10^{-3}$ & 261.8 & 252.2 & $2.63 \times 10^{-2}$ \\
\hline $10^{-2}$ & $2.0 \times 10^{-4}$ & $8.3 \times 10^{-3}$ & 232.0 & 233.5 & 0 \\
\hline $\begin{array}{l}\text { Arsenic(V) } \\
\text { Concentration }\end{array}$ & $\begin{array}{c}\text { Arsenic(III) }[\text { As }(I I I)]_{1} \\
\text { Concentration }\end{array}$ & $\begin{array}{c}\text { Arsenic(III) }[\text { As }(I I I)]_{2} \\
\text { Concentration }\end{array}$ & $\begin{array}{l}\mathrm{E}_{1} \\
\mathrm{mv}\end{array}$ & $\begin{array}{l}\mathrm{E}_{2} \\
\mathrm{mv}\end{array}$ & Ksc \\
\hline $10^{-5}$ & $10^{-6}$ & $10^{-3}$ & 258 & 201 & $2.42 \times 10^{1}$ \\
\hline $10^{-4}$ & $10^{-6}$ & $10^{-3}$ & 242.5 & 201 & $1.34 \times 10^{1}$ \\
\hline $10^{-3}$ & $10^{-6}$ & $10^{-3}$ & 229 & 199 & $3.16 \times 10^{1}$ \\
\hline $10^{-2}$ & $10^{-6}$ & $10^{-3}$ & 216.5 & 192.5 & $1.50 \times 10^{-2}$ \\
\hline
\end{tabular}


The selectivity constant is an approximate number which can be used only to estimate orders of magnitude of interference to be expected in a given case. It cannot be used to make corrections to electrode readings obtained in solutions which are contaminated with the interfering ions(24).

It is found both by experiments and theory that the arsenic(I.II) ion has an appreciable effect on the potential measurements. So, it is necessary to oxidize all the arsenic(III) to arsenic(V) before doing the measurements in order to get a meaningful result. 
SUMMARY

An arsenic(V) selective electrode was developed by preparing the coprecipitate of silvex sulfide and silver arsenate and pressing it into a thin membrane. From measurements of the response electrode as a function of membrane composition, arsenic(V) concentration and $\mathrm{pH}$ it was found that the electrode potential is dependent upon either $\mathrm{HAs}_{4}{ }^{-2}$ or $\mathrm{AsO}_{4}^{-3}$. The electrodes prepared with an excess of silver sulfide responded initially to $\mathrm{HAs}_{4}{ }^{-2}$ but after being in contact with the solution of $\mathrm{pH}$ about 8 or higher became responsive to $\mathrm{AsO}_{4}^{-3}$. This is explained by the $\mathrm{Ag}_{2} \mathrm{HAsO}_{4}$ in the membrane being converted to the more insoluble $\mathrm{Ag}_{3} \mathrm{AsO}_{4}$ on the electrode surface. The same effect could be accomplished by anodizing the electrode in a solution of arsenic(V) at $\mathrm{pH}$ 8. Electrodes prepared with an excess of silver arsenate showed inftially response to $\mathrm{As}_{4}{ }^{-3}$ since the form of the silver arsenate in the membrane was $\mathrm{Ag}_{3} \mathrm{AsO}_{4}$.

Calibration curves of potential as a function of arsenic(V) concentration under optimum conditions reveal that the electrodes can be used to measure concentrations as $10 \mathrm{w}$ as $10^{-5} \mathrm{M}(750 \mathrm{ppb})$.

Interferences due to arsenic(III) and phosphate were measured since these ions are often found with arsenic(v). The selectivity constants of the electrode for $\operatorname{arsenic}(V)$ in the presence of these two lons were $2.3 \times 10^{1}$ and $1.4 \times 10^{-2}$, respectively. So the concentration of arsenite must be kept less than $1 / 20$ th the arsenate concentration in order to avoid interference by arsenic(III). Phosphate interferences are less of a problem and concentrations even ten times greater than the arsenic(V) concentration produce little error. 
From the low solubility of silver arsenite at high $\mathrm{pH}$ values, it is apparent that an ion selective electrode could be made for arsenic(III) and that interferences due to arsenic(V) would be less than the converse situation above.

It may be concluded that optimum performance and stability of an arsenate-sensitive electrode would require having a high mole ratio of silver arsenate to silver sulfide. However, such a ratio also causes a decrease in the ionic conductivity of the membrane. Exactly where the compromise ratio is could be established by future experiments of the type used in this work. 


\section{BIBLIOGRAPHY}

1. L. M. Magnus on and T. C. Waugh, Science, 164, 389 (1970).

2. E. Scott Puttison, Science, 170, 870 (1970).

3. M. B. Jacobs and J. Nagler, Ind. Eng. Chem., Anal. Ed., 14, 442 (1942).

4. R. Thie1 and G. Carpentier, Bull. Centre Rech. Pau., 4, 243 (1970). (Cf. Anal. Abstr., 20, 1971, Abstr. No. 1341)

5. W. Holak, Ana1. Chem., 41, 1712 (1969).

6. R. E. Madsen, Jr., At. Absorp. Newslett., 10, 57 (1971).

7. F. J. Fernandez and D. C. Manning, ibid., p. 86.

8. E. F. Dalton and A. J. Malanoski, ibid., p. 92.

9. R. C. Chu, G. P. Barron, and P. A. W. Baumgarner, ibid., p. 1476.

10. F. E. Lichte and R. K. Skogerboe, ibid., p. 1480.

11. J. E. Portmann and J. P. Riley, Anal. Chim. Acta., 31, 509 (1964).

12. A. Zeman, J. Stary, and K. Kratzer, Radiochem. Radioanal. Lett., 4(1), 1 (1970).

13. V. Stara and J. Stary, Talanta., 17, 341 (1970).

14. D. L. Johnson and M. E. Q. Pilson, Anal. Chim. Acta., 58, 289 (1972).

15. David J. Myers and Janet Osteryoung, Anal. Chem., 45, 267 (1973).

16. G. W. C. Milner, The Principles and Applications of Polarography, 1957.

17. I. M. Kolthoff and J. J. Lingane, Polarography, 2, 542 (1952).

18. J. P. Arnold and R. M. Johnson, Talenta., 16, 1191 (1969).

19. RIchard A. Durst, Ion Selective electrodes, Washington, D. C. 77 (1969).

20. William F. Linke, Solubilities of Inorganic and Metal-organic Compounds., D. Van Nostrand Company, Inc. Princeton, New Jersey, 1958.

21. P. Sellers, S. Sunner, and I. Wadso, Acta Chem. Scand., 18202 (1964). 
22. L. G. Sillen, Chem. Soc. Lond. Spec. Pub. 17 (1964).

23. Richard A. Durst, Ion-Selective Electrode., Washington, D. C. 98 (1969).

24. Richard A. Durst, Ion Selective Electrode., Washington, D. C. 69 (1969). 


\section{APPENDIX}

For the arsenic(V) sensitive electrode, assuming that the preclpitate form in the membrane is $\mathrm{Ag}_{2} \mathrm{HAsO}_{4}$, the mass balance of arsenic(V) is

$$
\begin{aligned}
& {[\mathrm{As}(\mathrm{V})]=\left[\mathrm{H}_{3} \mathrm{AsO}_{4}\right]+\left[\mathrm{H}_{2} \mathrm{AsO}_{4}^{-}\right]+\left[\mathrm{HAsO}_{4}^{-2}\right]+\left[\mathrm{AsO}_{4}^{-3}\right]} \\
& =\frac{\left[\mathrm{HAsO}_{4}^{-2}\right]\left[\mathrm{H}^{+}\right]^{2}}{\mathrm{~K}_{1} \mathrm{~K}_{2}}+\frac{\left[\mathrm{HAsO}_{4}^{-2}\right]\left[\mathrm{H}^{+}\right]}{\mathrm{K}_{2}}+\left[\mathrm{HAsO}_{4}^{-2}\right]+\frac{\left[\mathrm{HAsO}_{4}^{-2}\right] \mathrm{K}_{3}}{\left[\mathrm{H}^{+}\right]} \\
& \left.=\left[\mathrm{HAsO}_{4}^{-2}\right]\left[\frac{\left[\mathrm{H}^{+}\right]^{2}}{\mathrm{~K}_{1} \mathrm{~K}_{2}}+\frac{\left[\mathrm{H}^{+}\right]}{\mathrm{K}_{2}}+\right]+\frac{\mathrm{K}_{3}}{\left[\mathrm{H}^{+}\right]}\right] \\
& \text {If } \alpha=\frac{\left[\mathrm{H}^{+}\right]^{2}}{\mathrm{~K}_{1} \mathrm{~K}_{2}}+\frac{\left[\mathrm{H}^{+}\right]}{\mathrm{K}_{2}}+1+\frac{\mathrm{K}_{3}}{\left[\mathrm{H}^{+}\right]} \\
& \text {By rearranging } \frac{\left[\mathrm{HAsO}_{4}^{-2}\right]}{[\mathrm{As}(\mathrm{V})]}=\frac{1}{\alpha}
\end{aligned}
$$

The silver electrode-potential is given as

$$
E=\text { constant }+0.059 \log \left[\mathrm{Ag}^{+}\right]
$$

Since $\left[\mathrm{Ag}^{+}\right]=\frac{\mathrm{Ksp}}{\left[\mathrm{HAsO}_{4}^{-2}\right]} \quad \frac{1}{2}$

where $\mathrm{Ksp}=$ solubility product of $\mathrm{Ag}_{2} \mathrm{HAs}_{4}$.

By substitution of 7 into the potential expression 6 we get the potential for the arsenic(V) sensitive electrode as follows:

$$
\begin{aligned}
& E=\text { constant }-\frac{0.059}{2} \log \frac{\left[\mathrm{HAsO}_{4}^{-2}\right.}{\mathrm{Ksp}} \\
& \text { Since }\left[\mathrm{HAs}_{4}^{-2}\right]=\frac{[\mathrm{As}(\mathrm{V})]}{\alpha} \\
& E=\text { constant }-\frac{0.059}{2} \log \frac{[\mathrm{As}(\mathrm{V})]}{\mathrm{Ksp} \cdot \alpha} \\
& \quad=\text { constant }-0.0295 \log [\mathrm{As}(\mathrm{V})]+0.0295 \log \mathrm{Ksp} \\
& +0.0295 \log \alpha
\end{aligned}
$$


Since $[A s(V)]$ and Ksp are constants, all the constant terms may be expresséd as $k^{\prime}$

$$
E=k^{\prime}+0.0295 \log \alpha
$$

The values of $E$ were calculated from equation 9 over the full pH range and are plotted in Figure 2. The constant value was adjusted in order to coincide with the experimental curve over $\mathrm{pH}=7-9$.

Based on the precipitate $\mathrm{Ag}_{3} \mathrm{AsO}_{4}$, the mass balance of arsenic(V) is

$$
\begin{aligned}
& {[\mathrm{As}(\mathrm{V})]=\left[\mathrm{H}_{3} \mathrm{AsO}_{4}\right]+\left[\mathrm{H}_{2} \mathrm{AsO}_{4}-\right]+\left[\mathrm{HAsO}_{4}^{-2}\right]+\left[\mathrm{AsO}_{4}^{-3}\right]} \\
& =\frac{\left[\mathrm{H}^{+}\right]^{3}\left[\mathrm{AsO}_{4}^{-3}\right]}{\mathrm{K}_{1} \mathrm{~K}_{2} \mathrm{~K}_{3}}+\frac{\left[\mathrm{H}^{+}\right]^{2}\left[\mathrm{AsO}_{4}^{-3}\right]}{\mathrm{K}_{2} \mathrm{~K}_{3}}+\frac{\left[\mathrm{H}^{+}\right]\left[\mathrm{AsO}_{4}^{-3}\right]}{\mathrm{K}_{3}}+\left[\mathrm{AsO}_{4}^{-3}\right] \\
& =\left[\mathrm{AsO}_{4}^{-3}\right]\left(\frac{\left[\mathrm{H}^{+}\right]^{3}}{\mathrm{~K}_{1} \mathrm{~K}_{2} \mathrm{~K}_{3}}+\frac{\left[\mathrm{H}^{+}\right]^{2}}{\mathrm{~K}_{2} \mathrm{~K}_{3}}+\frac{\left[\mathrm{H}^{+}\right]}{\mathrm{K}_{3}}+1\right) \\
& \text { if } \frac{\left[\mathrm{H}^{+}\right]^{3}}{\mathrm{~K}_{1} \mathrm{~K}_{2} \mathrm{~K}_{3}}+\frac{\left[\mathrm{H}^{+}\right]^{2}}{\mathrm{~K}_{2} \mathrm{~K}_{3}}+\frac{\left[\mathrm{H}^{+}\right]}{\mathrm{K}_{3}}+1=\beta \frac{\left[\mathrm{AsO}_{4}^{-3}\right]}{[\mathrm{As}(\mathrm{V})]} \frac{1}{\beta} \\
& \text { Since }\left[\mathrm{Ag}^{+}\right]=\left(\frac{\mathrm{Ksp}}{\left[\mathrm{AsO}_{4}^{-3}\right]}\right)^{1 / 3} \\
& \text { where } \mathrm{Ksp}=\text { solubility product of } \mathrm{Ag}_{3} \mathrm{AsO}_{4}
\end{aligned}
$$

By substitution of 10 into the equation 6 we get the potential for the arsenic(V) sensitive electrode based on $\mathrm{Ag}_{3} \mathrm{AsO}_{4}$ as follows:

$$
\begin{aligned}
& E=\text { constant }-\frac{0.059}{3} \log \frac{\left[\mathrm{AsO}_{4}^{-3}\right]}{\mathrm{Ksp}} \\
& \text { since }\left[\mathrm{AsO}_{4}^{-3}\right]=\frac{[\mathrm{As}(\mathrm{V})]}{\beta} \\
& E=\text { constant }-\frac{0.059}{3} \log \frac{[\mathrm{As}(\mathrm{V})]}{\mathrm{Ksp} \cdot \beta}
\end{aligned}
$$

since $[\mathrm{As}(\mathrm{V})], \mathrm{Ksp}_{3} \mathrm{Ag}_{4} \mathrm{As}_{4}$ are constants,

we get $E=k^{\prime \prime}+0.02 \log \beta$

The values of $\mathrm{E}$ were calculated from equation 11 over the $\mathrm{pH}$ range 3 to 12 and plotted in Figure 2. The constant value was adjusted in order 
to coincide with the experimental curve over $\mathrm{pH}=9$ to 12 . 